THE KURUME MEDICAL JOURNAL

Vol.29, Supplement, p. S137-S149, 1982

\title{
Carcinoma of the Thyroid Gland
}

\section{-A Retrospective Investigation of 75 Patients-}

\author{
SHINYA ARAKI, YOSHIO HIRADE, MASAMI ASO AND SHIGENOBU MIHASHI \\ Department of Otolaryngology, Kurume University, School of Medicine, \\ Kurume, 830 Japan
}

Received for publication April 10, 1982

\begin{abstract}
Summary: A retrospective review was completed of 69 patients treated at Kurume University Hospital from 1971 to 1980 for carcinoma of the thyroid gland. Sixty-one cases underwent curative treatments and 8 were subjected to palliative treatments. The results of this retrospective study are summarized as follows: (1) In the patients of curative treatments, 5-year and 10-year cumulative survival rates calculated by the actuarial method were $76.8 \%$ and $63.0 \%$, respectively. (2) The factors which presented significant influences on the prognosis were age, histological type and surgical treatment. (3) All of the undifferentiated carcinoma cases died from primary lesion. (4) The patients over 65 years old tended to present lower survival rates than did the younger patients. (5) In both of the 2 cases of isthmus carcinoma which was treated by a localized removal, a local recurrence developed.
\end{abstract}

Key words: carcinoma - thyroid gland - carcinoma of thyroid gland - survival rate-cause of death

\section{Introduction}

Carcinoma of the thyroid gland can be divided into two major histological types which are markedly different in prognosis: undifferentiated and differentiated types. The former presents very poor prognosis while the latter can be rather easily controlled. The majority of the cases reviewed in this paper are carcinomas of differenciated types.

Okada et al. (1976) previously reviewed 51 cases treated at Kurume University Hospital between 1960 and 1973. The crude 5 -year survival rate was $65.0 \%$. There were 16 deaths of which 7 were from the primary tumor, 7 from distant metastasis, and 2 from intercurrent diseases. On the basis of these results, we felt it was necessary to evaluate our endeavors and to de termine if improved treatments of the primary lesion increased the survival rate. It was, therefore, the purpose of this paper to review the cases treated between 1971 and 1980 , to relate histological type and age to prognosis, and to discuss varying treatments, in order that we might obtain some suggestions for the future improvement in managing this disease.

\section{Materials and Methods}

During the 10 year priod between January 1, 1971 and December 31, 1980, 166 patients with thyroid gland disease were treated at the Department of Otolaryngology, Kurume University Hospital. Eighty two patients had malignant neoplasm, 64 benign neoplasm and, 20 non-neoplastic diseases such as hyperthyroidism or thyroiditis (Table 1). In 7 of 82 malignant cases, no histological diagnosis was available. The classification of histological types 
TABLE 1

Histological types of 166 cases of thyroid gland disease (1971-1980)

\begin{tabular}{|c|c|c|c|c|}
\hline & Histological type $\quad$ sex & Male & Female & Total \\
\hline Benign neoplasm & $\begin{array}{l}\text { Follicular adenoma } \\
\text { Adenomatous goiter }\end{array}$ & $\begin{array}{l}7 \\
0\end{array}$ & $\begin{array}{r}48 \\
9\end{array}$ & $\left.\begin{array}{r}55 \\
9\end{array}\right\} 64$ \\
\hline Malignant tumor & $\begin{array}{l}\text { Papillary carcinoma } \\
\text { Follicular carcinoma } \\
\text { Medullary carcinoma } \\
\text { Undifferentiated carcinoma } \\
\text { No histological diagnosis available* }\end{array}$ & $\begin{array}{l}6 \\
4 \\
0 \\
2 \\
3\end{array}$ & $\begin{array}{r}45 \\
12 \\
1 \\
5 \\
4\end{array}$ & $\left.\begin{array}{r}16 \\
16 \\
1 \\
7 \\
7\end{array}\right\}$ \\
\hline \multicolumn{2}{|c|}{$\begin{array}{l}\text { Inflammation (Thyroiditis) } \\
\text { Hyperthyroidism }\end{array}$} & $\begin{array}{l}1 \\
4\end{array}$ & $\begin{array}{l}7 \\
8\end{array}$ & $\left.\begin{array}{r}8 \\
12\end{array}\right\} 20$ \\
\hline & Total & 27 & 139 & 166 \\
\hline
\end{tabular}

* All these 7 cases were clinically malignant.

is based on the general rules for the description of thyroid neoplasms proposed by the Japanese Society of Thyroid Surgery (1977). In this paper, we will review $75 b$ patients with histologically proven malignant neoplasm.

Of these 75 patients, 69 had received no previous treatment whereas 6 were previously treated at other clinics. Among the former 69 patients, 61 were curatively treated at our hospital and the other 8 were subjected to palliative treatments. Of those patients receiving treatment elsewhere, 5 were curatively treated and the other patient received palliative treatment.

Table 2 presents a distribution of 75 patients by sex and age. There were 11 males and 64 females. Thus, the number of females was greater than that of males. The ratio of males to females was approximately $1: 6$. The age of the 75 patients ranged from 21 to 79 with a mean age of 57 years. The average age were 44 years with a range from 11 to 75 years for benign neoplasms and 39 with a range from 11 to 76 years for non-neoplastic lesions. Fig. 1. presents the distribution of the 166 cases of thyroid diseases by age. There was a marked dif ference in the peak age of occurrence between benign diseases and malignant neo-
TABLE 2

Distribution of 75 patients of carcinoma of the thyroid gland by sex and age

\begin{tabular}{ccc|r}
\hline Age group & Male & Female & Total (\%) \\
\hline $20-29$ & 1 & 6 & $7(9)$ \\
$30-39$ & 1 & 5 & $6(8)$ \\
$40-49$ & 0 & 8 & $8(11)$ \\
$50-59$ & 3 & 11 & $14(19)$ \\
$60-69$ & 4 & 18 & $22(29)$ \\
$70-79$ & 2 & 16 & $18(24)$ \\
\hline Total & 11 & 64 & $75(100)$ \\
\hline
\end{tabular}

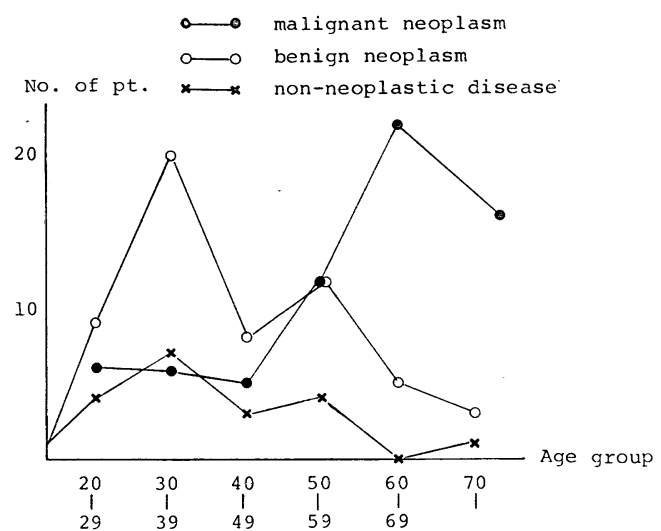

Fig. 1. Distribution of 166 thyroid gland disease by age 
TABLE 3

Distribution of 69 cases by histological diagnosis and $T$ and $N$ categories

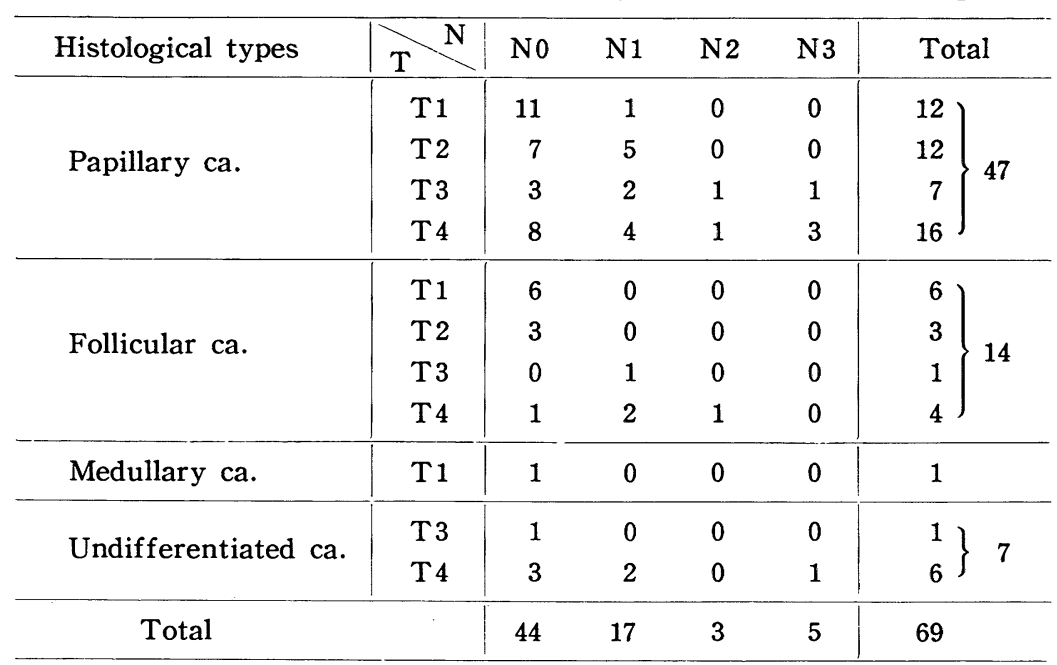

plasms of the thyroid gland. Benign diseases occurred most frequently in the forth decade while malignant neoplasms occurred in the seventh decade.

Table 3 presents the distribution of the 69 primary cases by histological types and $\mathrm{T}$ and $\mathrm{N}$ categories. TNM categories were based on the UICC TNM classification (UICC, 1978). Among the entire group of 69 cases, $47(68 \%)$ cases were papillary carcinoma, 14 (20\%) follicular carcinoma, one medullary carcinoma and $7(10 \%)$ undifferentiated carcinoma. With respect to $\mathrm{T}$ category, there were $19 \mathrm{~T} 1(28 \%), 15$ T2:(22\%), 9 T3 (13\%) and $26 \mathrm{~T} 4(38 \%)$ cases. Forty-four cases $(63 \%)$ were staged N0, $17(25 \%)$ were N1, $3(4 \%)$ were N2 and $5(7 \%)$ were N3. A11 69 cases were staged M0.

Follow up examinations were indicated twice a month during the first 6 months, once a month during the following 6 months, once every 2 months during the second year, once every 3 months during the third year, once every $1 / 2$ to 1 year after the third year. Questionaries were used to determine the status of those patients who did not return to their scheduled follow up examinations. Analysis of the results of the treatments were based on patient status as of May 31, 1981.

\section{Results}

The results will be presented chiefly for those 61 patients who underwent curative treatment for the first time at our hospital. The results of those patients treated with palliative methods or cases that had been previously treated elsewhere are discussed separately and described in the latter part of this paper.

\section{Survival rate}

The cummulative survival rate of the 61 patients is presented in Fig. 2. It was calculated by the actuarial method (UICC, 1974). The onset chosen to compute survival rate is the date of hospitalization which generally coincided within a few days of initiation of treatment. The 5- and 10 year cumulative survival rates were $76.8 \%$ and $63.0 \%$ respectively. For the $56 \mathrm{pa}$ tients with differentiated carcinoma, 5year and 10-year cumulative survival rates 


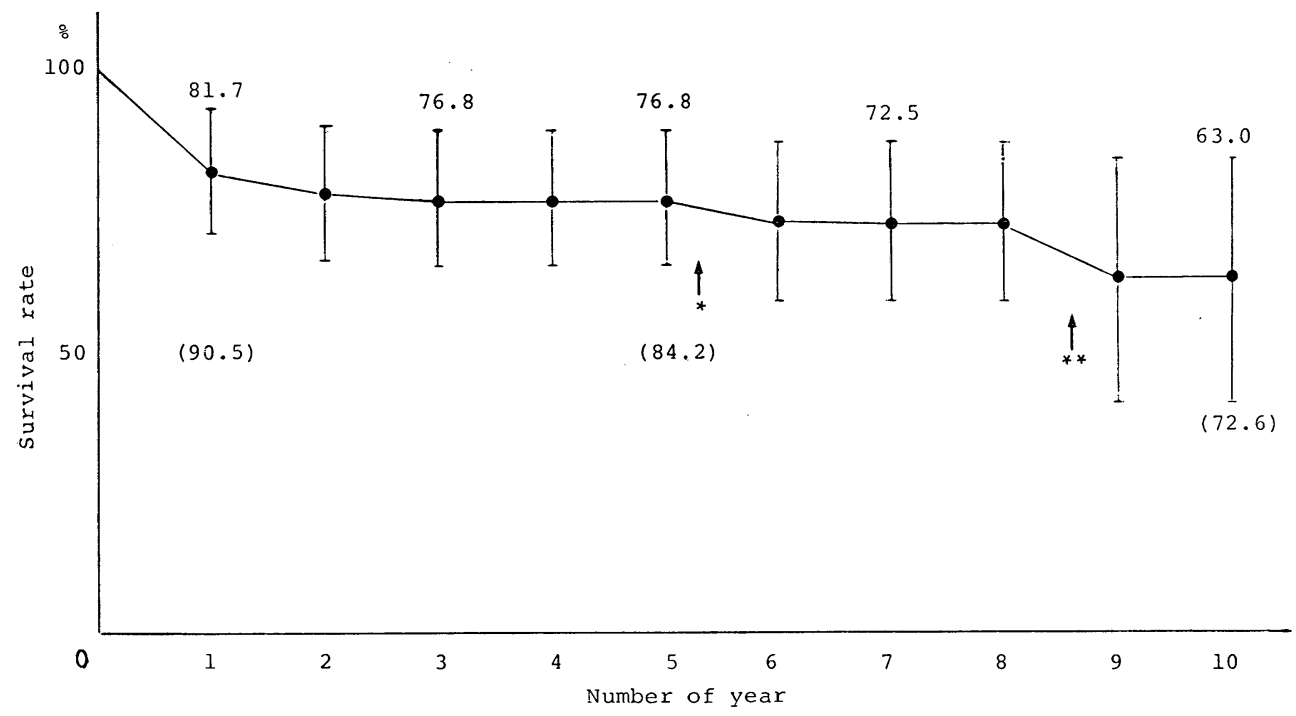

Fig. 2. Cumulative survival rate calculated by the actuarial method. 61 cases treated in $1971-1980$.

* One patient died from heart disease 5 years and 6 months after initial treatment.

** One patient died from natural death 8 years and 9 months after initial treatment.

Numbers in parentheses are the cumulative survival rates for differentiated carcinomas.

TABLE 4

Five-year cumulative survival rates (in per cent) calculated by the actuarial method for 61 patients curatively treated for the first time between 1971 and 1980.

\begin{tabular}{|c|c|c|c|}
\hline & & No. of pt. & 5-year \\
\hline $\begin{array}{l}\text { Histological } \\
\text { types }\end{array}$ & $\begin{array}{l}\text { Papillary ca. } \\
\text { Follicular ca. } \\
\text { Medullary ca. } \\
\text { Undifferenciated ca. }\end{array}$ & $\begin{array}{r}42 \\
13 \\
1 \\
5\end{array}$ & $\begin{array}{c}78.8 \\
88.9 \\
100.0 \\
0\end{array}$ \\
\hline $\mathrm{T}^{*}$ & $\begin{array}{l}\text { T1 } \\
\text { T2 } \\
\text { T3 } \\
\text { T4 }\end{array}$ & $\begin{array}{r}19 \\
15 \\
8 \\
14\end{array}$ & $\begin{array}{l}80.2 \\
90.9 \\
62.5 \\
75.0\end{array}$ \\
\hline $\mathrm{N}^{*}$ & $\begin{array}{l}\text { N0 } \\
\text { N1 } \\
\text { N2 and } 3\end{array}$ & $\begin{array}{r}37 \\
14 \\
5\end{array}$ & $\begin{array}{l}78.7 \\
74.1 \\
* *\end{array}$ \\
\hline
\end{tabular}

* Five undifferentiated carcinoma cases are excluded.

** Cumulative survival rate was not available since all surviving patients withdrew before the year indicated. 
were $84.2 \%$ and $72.6 \%$ respectively. As will be shown later, all deaths caused by the tumor present occurred within five years from the beginning of the treatment. The decrease in survival rate from the end of the 5th year to the end of the 10th year resulted, primarily from deaths from intercurrent diseases.

Table 4 compared 5 -year survival rates by histological types and $\mathrm{T}$ and $\mathrm{N}$ categories. With respect to the histological types, the 5-year cumulative survival rates was $78.8 \%$ for papillary carcinoma, $88.9 \%$ for follicular carcinoma, $100 \%$ for medullary carcinoma and $0 \%$ for undifferentiated carcinoma. All 5 cases of undifferentiated carcinoma died within a year. Concerning $\mathrm{T}$ category, the survival rate was slightly higher for $\mathrm{T} 1$ and $\mathrm{T} 2$ than for $\mathrm{T} 3$ and $\mathrm{T} 4$. With respect to $\mathrm{N}$ category, there was no marked difference in survival rate between N0 and N1. Five-year survival rate was not available for N2 and N3. There were two cases of N2: one case died within 3 years from the onset of the first surgery and the other was alive but withdrew by the beginning of the fourth year. Of the three cases of N3, one died within one month after initial surgery whereas the remaining two withdrew by the beginning of the second and the fifth year, respectively.

Table 5 presents 5 -year cumulative sirvival rates calculated by the actuarial method for 3 different age groups. The survival rate was the lowest for the oldest age group whereas the survival rate at 5 years was $100 \%$ for the patients under 50 years of age. Noteworthy is the fact that 4 cases of undifferentiated carcinoma belonged to the age group over 66 years of age and one to the age group of 51-65 years. However, even when the cases of undifferentiated carcinoma were excluded from the data the lower survival rate for the older age group was still obvious. Additionally, when the survival rates were compaired to the expected survival rate for each age group, there was still the tendency that the prognosis became poorer as the age became older.

TABLE 5

Five-year cumulcative survival rates (in per cent) calculated by the actuarial method for three different age groups.

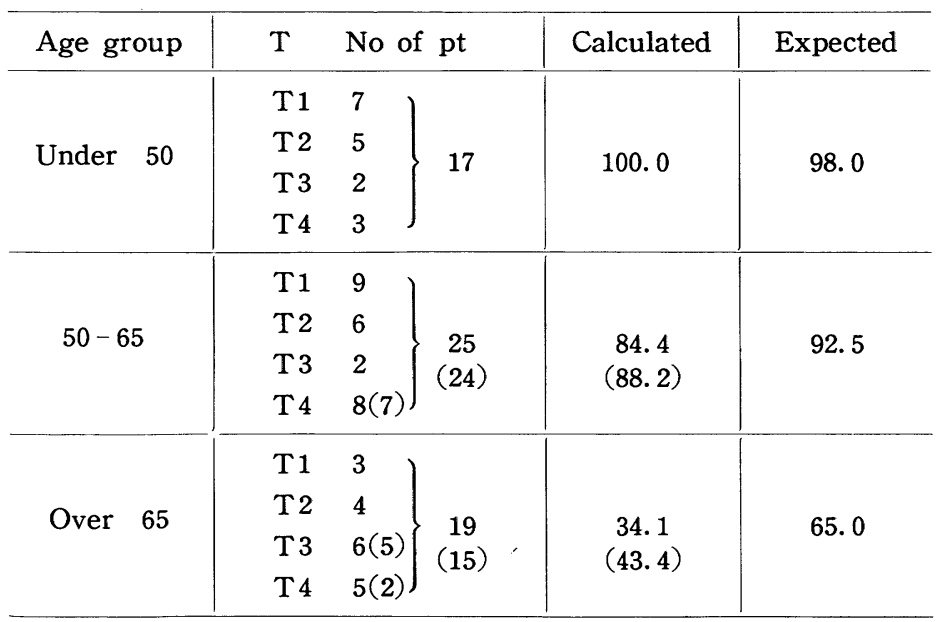

The numbers in parentheses present the data for well differentiated cacrinoma excluding 5 cases of undifferentiated carcinoma. 


\section{Cause of death}

The cause of death was classified and defined as follows:

(a) Death from primary lesion $(\mathrm{T})$. Patients who died with primary lesion uncontrolled with or without neck and/or distant metastasis were classified into this category.

(b) Death from neck metastasis $(\mathrm{N})$. Patients who died with neck metastasis uncontrolled, with primary lesion controlled with or without distant metastasis were classified into this category.

(c) Death from distant metastasis (M). Patients who died with distant metastasis with primary and neck controlled were classified into this category.

(d) Surgical death. Patients who died within 30 days after major surgical treatment were classified into this category.

(e) Death from complication. Patients who died of complication caused by any therapeutic intervention were classified into this category. Surgical death is one kind of death resulting from complications. In this paper, surgical death is described separately from those occuring from other complications.

(f) Unknown. Dead patients of whom no information about the cause death was available were classified into this category.

(2) Death from intercurrent disease.

Patients who died of intercurrent disease and had no evidence of the carcinoma present were classified into this category.

This definition is primarily based on the proposal by the Japan Society of Head and Neck Tumor (1981). The deaths from primary, neck metastasis and distant metastasis were defined according to Hirano et al. (1976).

Table 6 shows the cause of death of 17 patients. Fourteen $(82 \%)$ died of the tumor present and $3(18 \%)$ of intercurrent disease. The cause of death was primary lesion in $8(47 \%)$, distant metastasis in 2 (12\%) and surgical or other complications in $4(24 \%)$. Ten patients $(59 \%)$ died with -

TABLE 6

Cause of death by number of years of survival for 17 patients undergoing curative treatments.

\begin{tabular}{|c|c|c|c|c|c|c|}
\hline \multirow{2}{*}{ year* } & \multicolumn{4}{|c|}{ Death from tumor } & \multirow{2}{*}{$\begin{array}{l}\text { Intercurrent } \\
\text { disease }\end{array}$} & \multirow{2}{*}{ Total } \\
\hline & $\mathrm{T}$ & M & Surgery & Complication & & \\
\hline $0-1$ & 6 & 0 & 3 & 1 & 0 & 10 \\
\hline $1-2$ & 2 & 0 & 0 & 0 & 0 & 2 \\
\hline $2-3$ & 0 & 1 & 0 & 0 & 1 & 2 \\
\hline $3-4$ & 0 & 1 & 0 & 0 & 0 & 1 \\
\hline $4-5$ & 0 & 0 & 0 & 0 & 0 & 0 \\
\hline $5-6$ & 0 & 0 & 0 & 0 & 1 & 1 \\
\hline $6-7$ & 0 & 0 & 0 & 0 & 0 & 0 \\
\hline $7-8$ & 0 & 0 & 0 & 0 & 0 & 0 \\
\hline $8-9$ & 0 & 0 & 0 & 0 & 1 & 1 \\
\hline $9-$ & 0 & 0 & 0 & 0 & 0 & 0 \\
\hline Total & 8 & 2 & 3 & 1 & 3 & 17 \\
\hline
\end{tabular}

* Year after the onset of treatment

$\mathrm{T}$ : Death from primary lesion

$\mathrm{M}:$ Death from distant metastasis 
TABLE 7

Causes of death by histological types, $T$ and $N$ categories

\begin{tabular}{|c|c|c|c|c|c|c|c|c|}
\hline & & \multirow{2}{*}{$\begin{array}{l}\text { No. of } \\
\text { pt. }\end{array}$} & \multicolumn{4}{|c|}{ Death from tumor } & \multirow{2}{*}{$\begin{array}{l}\text { Intercurrent } \\
\text { disease }\end{array}$} & \multirow{2}{*}{ Total } \\
\hline & & & $\mathrm{T}$ & M & Surgery & Complication & & \\
\hline \multirow{4}{*}{$\begin{array}{c}\text { Histological } \\
\text { types }\end{array}$} & Papillary ca. & 42 & 3 & 0 & 3 & 1 & 2 & 9 \\
\hline & Follicular ca. & 13 & 0 & 2 & 0 & 0 & 1 & 3 \\
\hline & Medullary ca. & 1 & 0 & 0 & 0 & 0 & 0 & 0 \\
\hline & $\begin{array}{l}\text { Undifferen- } \\
\text { tiated ca. }\end{array}$ & 5 & 5 & 0 & 0 & 0 & 0 & 5 \\
\hline \multirow{4}{*}{$\mathrm{T}^{*}$} & $\mathrm{~T} 1$ & 19 & 2 & 1 & 0 & 0 & 0 & 3 \\
\hline & $\mathrm{T} 2$ & 15 & 0 & 1 & 0 & 0 & 1 & 2 \\
\hline & $\mathrm{T} 3$ & $9(1)$ & $1(1)$ & 0 & 1 & 1 & 2 & $5(1)$ \\
\hline & $\mathrm{T} 4$ & $18(4)$ & $5(4)$ & 0 & 2 & 0 & 0 & $7(4)$ \\
\hline \multirow{3}{*}{$\mathrm{N}^{*}$} & No & $41(4)$ & $6(4)$ & 2 & 1 & 0 & 1 & $10(4)$ \\
\hline & $\mathrm{N} 1$ & 14 & 0 & 0 & 1 & 0 & 2 & 3 \\
\hline & $\mathrm{N} 2$ and 3 & $6(1)$ & $2(1)$ & 0 & 1 & 1 & 0 & $4(1)$ \\
\hline
\end{tabular}

* Number in parentheses is that of undifferentiated carcinoma

TABLE 8

Types of treatment for the primary tumor by incidence of local recurrence and cause of death of 56 cases of well differentiated carcinoma

\begin{tabular}{|c|c|c|c|c|c|c|c|c|c|}
\hline \multirow{2}{*}{ Types of surgery } & \multirow{2}{*}{$\begin{array}{c}\text { No. of } \\
\text { pt. * }\end{array}$} & \multirow{2}{*}{$\begin{array}{l}\text { Local } \\
\text { recur- } \\
\text { rence }\end{array}$} & \multirow{2}{*}{ alive } & \multirow{2}{*}{ dead } & \multicolumn{4}{|c|}{ Cause of death } & \multirow{2}{*}{$\begin{array}{l}\text { Intercurrent } \\
\text { disease }\end{array}$} \\
\hline & & & & & $\mathrm{T}$ & M & Surgery & $\begin{array}{l}\text { Compli- } \\
\text { cation }\end{array}$ & \\
\hline Partial thyroidectomy & $2(2)$ & 2 & 0 & 2 & 1 & $1 * *$ & 0 & 0 & 0 \\
\hline Hemithyroidectomy & $33(28)$ & 1 & 28 & 4 & 0 & 1 & 1 & 0 & 2 \\
\hline $\begin{array}{l}\text { Hemithyroidectomy plus } \\
\text { radiation }\end{array}$ & $3(3)$ & 1 & 2 & 1 & 1 & 0 & 0 & 0 & 0 \\
\hline Subtotal thyroidectomy & $10(9)$ & 1 & 10 & 0 & 0 & 0 & 0 & 0 & 0 \\
\hline Total thyroidectomy & $8(4)$ & 1 & 3 & 5 & 1 & 0 & 2 & 1 & 1 \\
\hline
\end{tabular}

* Number in parentheses indicates number of patients where death occurred within 2 years from causes other than primary tumor and patients who withdrew alive within 2 years are excluded (10 patients in total are thus excluded).

** This patient developed pulmonary metastasis following repeated recurrences at the primary site and neck.

in one year, $12(71 \%)$ within two years and $14(82 \%)$ within three years. All the 14 deaths caused by the tumor present took place within four years of initial treatment. There were no deaths from neck metastasis.

Table 7 presents distribution of the cause of death by histological types and $\mathrm{T}$ and $\mathrm{N}$ categories. All five cases of undifferentiated carcinoma died from primary lesions. The remaining 3 deaths from primary lesions and all of the 4 deaths from complications occurred in papillary carcinoma cases whereas both deaths from distant metastasis resulted from follicular carcinoma. There was no relationship between the cause of death and $\mathrm{T}$ and $\mathrm{N}$ categories in the cases of differentiated carcinoma.

\section{Control of primary tumor}

Table 8 presents the type of treatment 
for the primary tumor by frequency of local recurrence and the cause of death.

The types of surgery were classified into 4 groups:

(1) Hemithyroidectomy. This was indicated when the carcinomatous lesion was localized within one lobe of the thyroid gland.

(2) Partial thyroidectomy. When carcinoma was localized in the inthmus, it was removed with some safety margin. In this paper, this procedure is referred to as a partial thyroidectomy.

(3) Subtotal thyroidectomy. When the thy roid lobe on the contralateral side was partially involved, major portion of the thyroid gland was removed.

(4) Total thyroidectomy. For more advanced cases, the entire thyroid gland was removed.

There were 6 cases of local recurrence. In five $(83 \%)$ of the 6 cases, local recurrence took place within 2 years after the onset of treatment. The only exception was a case who developed local recurrence 4 years and 1 month after the onset of treatment. In order to present meaningful data on the rate of local recurrence, cases dead within 2 years from causes other than local recurrence and surviving cases which were less than 2 years post initial treatment should be excluded from the analysis. Consequently, in Table 8 , the number of patients after these exclusions in indicated in parentheses. As seen from this Table, there were $2(100 \%)$ local recurrence in partial thyroidectomy. Subtotal or total thyroidectomy should have been indicated for these inthmus lesions. Three of the 6 patients who developed local recurrence died from the primary lesion, 2 are alive with the local recurrence supressed with hormone therapy and 1 died from distant metastasis with local tumor surgically controlled.

Table 9 presents the incidence of local recurrence by type of surgery for the primary tumor and $\mathrm{T}$ category. No significant relationship was observed between the $\mathrm{T}$ category.

TABLE 9

Type of surgery for the primary tumor and incidence of local recurrence of 56 surgical cases

\begin{tabular}{l|c|c|c}
\hline & T & No. of pt. & Local recurrence \\
\hline Partial thyroidectomy & T3 & $2(2)$ & 2 \\
\hline \multirow{4}{*}{ Hemithyroidectomy } & T1 & $16(13)$ & 1 \\
& T2 & $12(12)$ & 1 \\
& T3 & $2(2)$ & 0 \\
& T4 & $6(4)$ & 0 \\
\hline \multirow{5}{*}{ Subtotal thyroidectomy } & T1 & $1(1)$ & 0 \\
& T2 & $3(2)$ & 0 \\
& T3 & $4(4)$ & 1 \\
& T4 & $2(2)$ & 0 \\
\hline \multirow{2}{*}{ Total thyroidectomy } & T3 & 3 & 1 \\
& T4 & $5(1)$ & 0 \\
\hline
\end{tabular}

* Number in parentheses indicate number of patients where death occurred within 2 years from causes other than primary tumor and patients who withdrew alive within 2 years are excluded (10 patients in total are thus excluded). 


\section{Control of neck metastasis}

As shown in Table 10, there was evidence of cervical lymphnode involvement in 20 patients on the affected side. For all patients with evidence of node involvement, radical neck dissection (RND) was executed. RND was also done in 9 of the 36 patients who presented no evidence of node involvement on the attected side. Of these 9 patients, 2 underwent RND with the internal jagular vein preserved whereas 7 had extirpation of the lymphnodes only.

Table 11 presents frequency of cervical recurrence. On the affected side, 4 patients developed cervical recurrence. One patient who had lymphnode extirpation at the initial treatment developed cervical recurrence associated with primary recurrence. Subtotal thyroidectomy and radical neck dissection was performed. The other 3 had no RND at the initial treatment and developed cervical recurrence without recurrence at the primary site. They should have had latent metastasis. There was no death from neck metastasis. The interval between the onset of treatment and the cervical recurrence was less than 1 year in $3(75 \%), 1$ to 2 years in 1 (25\%). Thus, $75 \%$ of cervical recurrence occurred within 1 year.
One of the ways to estimate the rate of occult neck metastasis is to examine the incidence of cervical recurrence without local recurrence in patients who had negative nodes and but who did not undergo RND. In this instance, the patiens who died or withdrew within 1 year without having neck recurrence should be excluded from the data. The rate of latent neck metastasis estimated in this way was 3 out of $26(12 \%)$ on the affected side.

\section{TABLE 10}

Condition of cervical lymphnodes in 56 patients of differentiated carcinoma and execution of $R N D$

\begin{tabular}{l|ll|lc}
\hline \multirow{2}{*}{ Side } & $\begin{array}{c}\text { Evidence of node } \\
\text { involvement }\end{array}$ & \multicolumn{2}{|c}{ R N D } \\
\cline { 3 - 5 } Affected & $\begin{array}{c}\text { Present } \\
\text { Absent }\end{array}$ & $(\mathrm{N}=20)$ & $20^{*}$ & 0 \\
& Abse & $9^{* *}$ & 27 \\
\hline \multirow{2}{*}{ Unaffected } & Present & $(\mathrm{N}=0)$ & 0 & 0 \\
& Absent & $(\mathrm{N}=56)$ & 0 & 56 \\
\hline
\end{tabular}

* In 1 case, extirpation of lymphnodes only was performed.

** In 2 cases, RND was performed with the internal juglar vein preserved and extirpation of lymphnodes only was done in the remaining 7 .

TABLE 11

Recurrence of cervical lymphnodes

\begin{tabular}{|c|c|c|c|c|}
\hline- & $\begin{array}{l}\text { Previous } \\
\text { RND }\end{array}$ & $\begin{array}{l}\text { Recurrence } \\
\text { of primary }\end{array}$ & $\begin{array}{l}\text { No. of cases of } \\
\text { cervical recurrence }\end{array}$ & Final status \\
\hline \multirow{2}{*}{ Affected side } & Done* & $\begin{array}{l}\text { Absent } \\
\text { Present }\end{array}$ & $\begin{array}{l}0 \\
1 *\end{array}$ & 1 controlled \\
\hline & Not done & $\begin{array}{l}\text { Absent } \\
\text { Present }\end{array}$ & $\begin{array}{l}3 * * \\
0\end{array}$ & 3 controlled \\
\hline
\end{tabular}

* In this case, lymphnode extirpation alone was initially performed. The recurrence was controlled with subtotal thyroidectomy and radical neck dissection.

** These 3 cases probably had latent neck metastasis. 


\section{Analysis of distant metastasis}

There were 2 patients who developed distant metastasis, both being cases of follicular carcinoma. Fig. 3 presents an outline of these patients. The metastasis was diagnosed only by $\mathrm{X}$-ray examination in both cases. The location of metastasis was the lung in one case and the fifth and sixth thoracic vertebrae in the other. One patient developed the distant metastasis without local and cervical recurrence. The other developed recurrences of the primary and neck which were surgically controlled. Following this she developed lung metastasis and died from it. The interval from the onset of treatment to the first recognition of the distant metastasis was 2 years and 10 months and 2 years and 3 months respectively.
6. Analysis of surgical death and complication

Three patients died from surgical complication and 1 from other complications. An outline of these cases were summarized in Fig. 4. Surgical death was caused by bleeding resulting from rupture of the common artery in 1 case and pneumonia in 2 . Another fatal complication was pmeumonia. In this case, necropsy revealed residual neck tumor and diffuse metastatic papillary carcinoma in the lung.

\section{Analysis of fatal intercurrent disease}

Three patients died of an intercurrent disease. Fig. 5. presents an outline of these patients. One died from natural death at the age of 76 and two died of heart disease.

\begin{tabular}{|c|c|c|c|c|c|}
\hline $\begin{array}{l}\text { Case Age } \\
\text { classific }\end{array}$ & $\begin{array}{l}\text { Sex } \\
\text { cation }\end{array}$ & $\begin{array}{l}\text { Initial } \\
\text { Treatment }\end{array}$ & $1 y$ & $2 y$ & $3 y$ \\
\hline $\begin{array}{l}\text { D-1 } 55 \\
\text { Follicular } \\
\text { TlNOM0 }\end{array}$ & $\begin{array}{c}\mathrm{F} \\
\mathrm{ca}\end{array}$ & $\mathrm{PT}$ & $\mathrm{H}+\underset{\times}{\mathrm{RND}(\ell)}$ & $\stackrel{T}{x}$ & Lung meta. \\
\hline $\begin{array}{l}\text { D-2 } \\
\text { Follicular } \\
\text { T2Nomo }\end{array}$ & $\begin{array}{c}\mathrm{F} \\
\mathrm{ca}\end{array}$ & $\mathrm{H}$ & 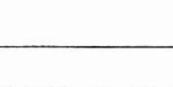 & Bone meta. & \\
\hline
\end{tabular}

Fig. 3. Outline of patients who died from distant metastasis

H : Hemithyroidectomy RND : Radical neck dissection

$\mathrm{T}:$ Total thyroidectomy $\circ$ : Distant metastasis recognized

PT : Partial thyroidectomy $\quad$ : Died $\quad \times$ : Recurrence

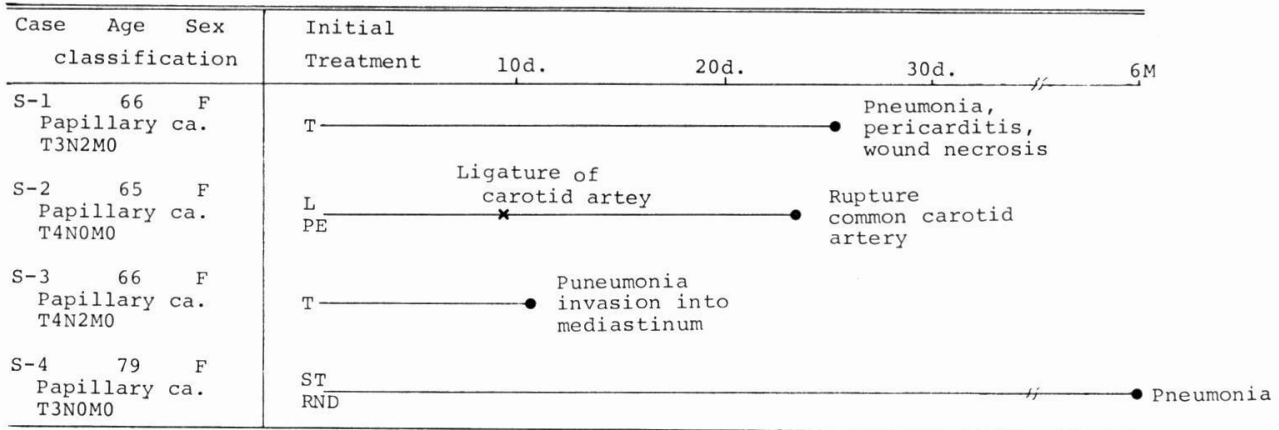

Fig. 4. Outline of patients who died from surgery and complications

P E : Pharyngoesophagotomy

S T : Subtotal thyroidectomy
$\mathrm{T}:$ Total thyroidectomy RND : Radical neck dissection 


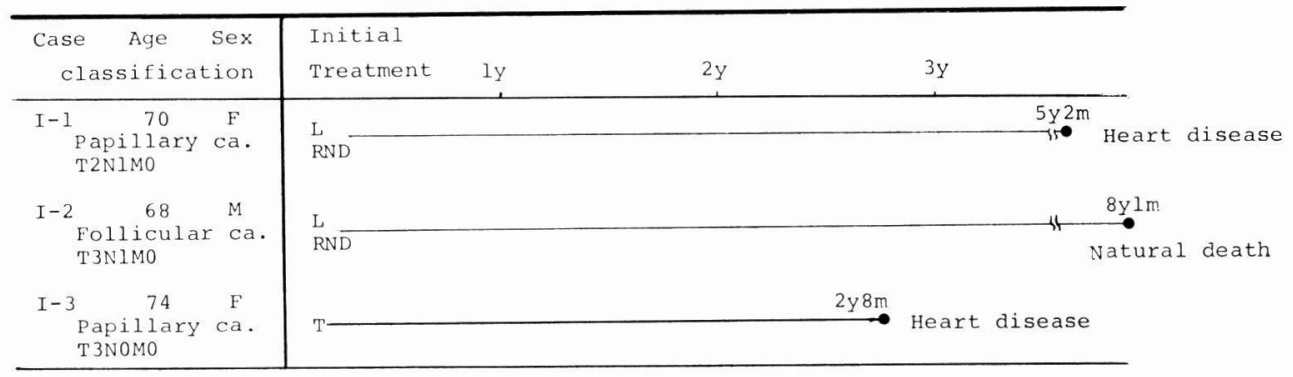

Fig. 5. Outline of patients who died from intercurrent disease

L : Hemithyroidectomy $\mathrm{T}:$ Total thyroidectomy RND : Radical neck dissection

TABLE 12

Analysis of palliative treated 8 cases

\begin{tabular}{|c|c|c|c|c|c|c|}
\hline Case & Age & Sex & T NM & Histological type & Therapy & Results \\
\hline$P-1$ & 71 & Female & T 4N3M0 & Papillary ca. & Radiation ${ }^{60} \mathrm{Co} 4200 \mathrm{rad}$ & $\begin{array}{l}\text { Alive, } 7 \text { years } \\
\text { and } 3 \text { months }\end{array}$ \\
\hline P - 2 & 71 & Female & T $4 \mathrm{~N} 0 \mathrm{M} 0$ & Papillary ca. & Partial removal & $\begin{array}{l}\text { Alive, } 5 \text { years } \\
\text { and } 2 \text { months }\end{array}$ \\
\hline $\mathrm{P}-3$ & 75 & Female & T $4 \mathrm{~N} 0 \mathrm{M} 0$ & Papillary ca. & Radiation ${ }^{60}$ Co $5400 \mathrm{rad}$ & $\begin{array}{l}\text { Alive, } 3 \text { years } \\
\text { and } 2 \text { months }\end{array}$ \\
\hline $\mathrm{P}-4$ & 56 & Male & $\mathrm{T} 4 \mathrm{~N} 1 \mathrm{M} 1$ & Undifferentiated ca. & Tracheostomy only & Died, 2 months \\
\hline$P-5$ & 69 & Male & $\mathrm{T} 4 \mathrm{~N} 1 \mathrm{M} 0$ & Undifferentiated ca. & Tracheostomy only & Died, 2 months \\
\hline $\mathrm{P}-6$ & 68 & Female & $\mathrm{T} 4 \mathrm{~N} 2 \mathrm{M} 0$ & Follicular ca. & Tracheostomy only & $\begin{array}{l}\text { Died, } 2 \text { years } \\
\text { and } 11 \text { months }\end{array}$ \\
\hline $\mathrm{P}-7$ & 61 & Female & T $4 \mathrm{~N} 0 \mathrm{M} 0$ & Papillary ca. & Partial removal & $\begin{array}{l}\text { Died, } 1 \text { year } \\
\text { and } 7 \text { months }\end{array}$ \\
\hline P - 8 & 75 & Male & $\mathrm{T} 4 \mathrm{~N} 1 \mathrm{M} 0$ & Papillary ca. & Partial removal & $\begin{array}{l}\text { Died, } 4 \text { years } \\
\text { and } 5 \text { months }\end{array}$ \\
\hline
\end{tabular}

TABLE 13

Analysis of previously treated 6 cases

\begin{tabular}{|c|c|c|c|c|c|}
\hline Age & Sex & Histology & Previously treatments & Treatment in our hospital & Results \\
\hline 40 & Female & Papillary ca. & Partial thyroidectomy & & $\begin{array}{l}\text { Alive, } 7 \text { ye } \\
\text { and } 2 \text { mont }\end{array}$ \\
\hline 78 & Female & Papillary ca & Surgery* & & $\begin{array}{l}\text { Alive, } 7 \\
\text { and } 1 \mathrm{mo}\end{array}$ \\
\hline 78 & Female & Papillary ca. & Hemithyroidectomy & $\begin{array}{l}\text { Tracheal fenestration } \\
\text { plus laser operation }\end{array}$ & $\begin{array}{l}\text { Alive, } 6 \text { years } \\
\text { and } 3 \text { months }\end{array}$ \\
\hline 27 & Female & Papillary ca. & Hemithyroidectomy & Radical neck dissection & Lost to follow ur \\
\hline 48 & & Follicular ca. & Surgery* & Tracheotomy only & $\begin{array}{l}\text { Died, } 1 \text { year } \\
\text { and } 5 \text { months }\end{array}$ \\
\hline 71 & Female & Papillary ca. & Total thyroidectomy & Radiation & Died, 8 months \\
\hline
\end{tabular}

* No information on the type of surgery was available. 


\section{Analysis of palliative cases}

For various reasons, 8 of the 69 patients were treated palliatively. These cases are summarized in Table 12. Seven patients were inoperable cases because of advanced lesions. Of these 7,3 underwent partial removal of the tumor, 3 tracheostomy only, and 1 palliative radiation therapy. One patient (Case P-1) refused radical surgery and underwent palliative radiation. Thyroid hormone therapy was applied to all these 8 cases.

Of these 8 patients, 5 died from the tumor present whereas 3 are currently alive for 3 years and 2 months, 5 years and 2 months and 7 years and 3 months respectively after the initial palliative treatment.

\section{Analysis of previously treated cases}

Six cases were previously treated at other hospitals. The outline of these cases is summarized in Table 13. Two patients had had hemithyroidectomy, 1 patient partial thyroidectomy and 1 patient total thyroidectomy as the previously treatment. The other 2 patients also had had surgery, but no information on the type of surgery was available. Of these 6 cases, 2 died from the tumor present, 3 are currently alive 6 or more years post treatment and 1 was lost to follow up 6 months after the surgical treatment in our hospital.

\section{Discussion}

Carcinoma of the thyroid gland can be devided into two major histological types which are markedly different in prognosis: undifferentiated and differentiated types. The former presents very poor prognosis while the latter can be rather easily controlled. The results of the present retrospective review confirm these previously reported difference in prognosis between these two histological types. All five cases of undifferentiated carcinoma died from primary lesion.

Table 14 shows the survival rate for carcinoma of the thyroid gland reported in some literature. The results of the present review present slightly lower survival rates compared to those reported by other authors. A possible reason for this is the fact that there were many advanced cases

TABLE 14

Survival rate reported in literature

\begin{tabular}{|c|c|c|c|c|c|}
\hline Authors & & $\begin{array}{l}\text { No. of } \\
\text { pt. }\end{array}$ & 5 -year & 10-year & Method of calculation \\
\hline Buckwalter (1961) & Well differenciated & 166 & & $\begin{array}{l}37.3 \text { (male) } \\
77.6 \text { (female) }\end{array}$ & Berkson's method \\
\hline Woolner (1961) & $\begin{array}{l}\text { Papillary ca. } \\
\text { Follicular ca. }\end{array}$ & $\begin{array}{l}471 \\
129\end{array}$ & $\begin{array}{l}93.3 \\
84.9\end{array}$ & $\begin{array}{l}82.0 \\
72.0\end{array}$ & Berkson's method \\
\hline $\begin{array}{l}\text { Inagaki, } \mathrm{H} . \\
(1968)\end{array}$ & $\begin{array}{l}\text { Papillary ca. } \\
\text { Follicular ca. }\end{array}$ & $\begin{array}{l}80 \\
31\end{array}$ & & $\begin{array}{r}84.2 \\
100.0\end{array}$ & Berkson's method \\
\hline Crile et al (1971) & Papillary ca. & 102 & 95 & 86.0 & Berkson's method \\
\hline Okada et al (1976) & Thyroid ca. & 20 & & 65.0 & Direct method \\
\hline $\begin{array}{l}\text { Mazzaberri et al } \\
\quad \text { (1977) }\end{array}$ & $\begin{array}{l}\text { Papillary ca. } \\
\text { Follicular } \\
\text { Medullary }\end{array}$ & 576 & 97.8 & 94.9 & $\begin{array}{l}\text { Cumulative } \\
\text { survival rate }\end{array}$ \\
\hline
\end{tabular}


and also there were a considerable number of patients of old ages. In the present review, it was shown that the prognosis became poor as the age was increased.

With respect to surgical technique, it should be emphasized that isthmus lesions call for an extensive surgical removal. Both of our 2 patients of an isthmus lesion died because the extent of the initial surgical removal was insufficient.

The results of the present review confirmed the effectiveness of thyroid hormone therapy which aimed at a suppression of TSH.

\section{References}

Buckwalter, J.A. (1961). Age and thyroid carcinoma. Arch. Surg. 82, 916-990.

CRILE, G. Jr. (1964). Survival of patients with papillary carcinoma of the thyroid after conservative operations. Am. J. Surg. 108, 862866.

INAGAKI, H. (1968). Statistical review of thyroid gland, carcinoma. Surg. Therapy, 18, 378380 .
Japan Society of Head and Neck Tumor (1981). Unpublished report.

Hirano, M., Shin, T., Minashi. S., Ichikawa, A., Minashi, K. and Hiroto, I. (1976). Long term results of treatments for carcinoma of the hypopharynx and/or cervical esophagus. Otologia (Fukuoka), 22, 737-747.

Mazzaferri, E.L., Young, R.L. and Oeptel, J. E. (1977). Papillary thyroid carcinoma: The impact of therapy in 576 patients. Medicine, 56, 171-196.

Okada, M., Ichikawa, A., Mihashi, S. and Hirano, M. (1976). A clinical study of malignant neoplasm of the thyroid gland. Otologia (Fukuoka), 22, 225-235.

The Japanese Society of Thyroid Surgery (1977). General rules for the description of thyroid cancer, Tokyo, Kanehara Press.

UICC (1974). TNM classification of malignant tumors. International Union Against Cancer, Geneva.

UICC (1978). TNM classification of malignant tumors. International Union Against Cancer, Geneva.

Woolner, L.B., Beahrs, O. H., Black, B. M., MIConahey, W. M. and Keatomg., F.R. (1961). Classification and prognosis of thyroid carcinoma. Am J. Surg. 102, 354-387. 